Original Article

\title{
GENETIC IMPROVEMENT OF ANTIDIABETIC ALPHA-GLUCOSIDASE INHIBITOR PRODUCING STREPTOMYCES SP
}

\author{
WALEED MOHAMED ABDULKHAIR ${ }^{*}$, WALAA SAID ABDEL-ALL2 ${ }^{2}$ REHAB HASAN BAHY ${ }^{3}$
}

${ }^{1 *}$ Researcher, General Department of Basic Medical Sciences, Microbiology Department, National Organization for Drug Control and Research, ${ }^{2}$ Associate Professor, General Department of Basic Medical Sciences, Microbiology Department, National Organization for Drug Control and Research, ${ }^{3}$ Researcher, General Department of Basic Medical Sciences, Microbiology Department, National Organization for Drug Control and Research

Email: waleed_hamada@yahoo.com

Received: 16 Feb 2018 Revised and Accepted: 29 Mar 2018

\begin{abstract}
Objective: This study aims to control type 2 of diabetes mellitus by a hypoglycemic substance that extensively produced by Streptomyces bacteria. The antidiabetic action of this substance depends on prevention of starch hydrolysis and then the liberation of glucose monomers via an inhibition
\end{abstract} of $\alpha$-glucosidase as one of starch hydrolyzing enzymes.

Methods: The strains of marine actinomycetes were isolated on starch nitrate agar, and then qualitatively and quantitatively screened to prevent starch hydrolysis. The most potent strain was identified by classical and genetical methods. The genetic improvement of the most potent strain was carried out by using UV radiations at different exposure periods per second. The optimization of environmental conditions was studied to obtain the maximum activity of the $\alpha$-glucosidase inhibitory protein, which purified and electrically separated to determine its molecular weight.

Results: Among 55 marine actinomycetes, only 7 strains were found have antidiabetic activity. This activity was assayed spectrophotometrically at 400 $\mathrm{nm}$, where $p$-nitrophenyl- $\alpha$-d-glucopyranoside and acarbose were used as a substrate and a positive control respectively. The most potent strain which marked as AD-7 was identified as Streptomyces coelicolor, which exposed to the genetic improvement using UV radiations to obtain a highly activity of an inhibitory protein at $10 \mathrm{~s}$ of the exposure period. The activity and stability continued for $5 \mathrm{~d}$ at $37^{\circ} \mathrm{C}$. The maximum activity and stability of an improved inhibitory protein were obtained with optimization of environmental conditions included inoculum size $\left(10^{6} \mathrm{cfu} / \mathrm{ml} / 300 \mu \mathrm{l}\right)$, incubation period $(14 \mathrm{~d})$, agitation speed $(160 \mathrm{rpm})$, incubation temperature $\left(30^{\circ} \mathrm{C}\right)$, and $\mathrm{pH}(8.5)$. An inhibitor was purified and separated at $34 \mathrm{KDa}$.

Conclusion: Alpha-glucosidase inhibitory protein as a powerful hypoglycemic agent was extracted from the filtrate of $S$. coelicolor. The mutant strain of the latter had been produced most active and stable inhibitory protein, which prevents the starch hydrolysis via an inhibition of $\alpha$ glucosidase enzyme for $5 \mathrm{~d}$ at $37^{\circ} \mathrm{C}$.

Keywords: Antidiabetic agents, Diabetes mellitus, Enzyme inhibitors, Physical mutagenesis, Starch hydrolysis

(C) 2018 The Authors. Published by Innovare Academic Sciences Pvt Ltd. This is an open access article under the CC BY license (http://creativecommons.org/licenses/by/4.0/) DOI: http://dx.doi.org/10.22159/ijpps.2018v10i5.25338

\section{INTRODUCTION}

Diabetes mellitus (DM) is a chronic disease arises from metabolic disorders, especially in the pancreatic gland. Simply, DM is an elevation of blood glucose level all the time (hyperglycemia) due to either deficient pancreatic insulin secretion or failed blood-insulin absorption [1]. So, the blood glucose level must be under full control to avoid the serious complications. There are two types of medical complications resulted from uncontrolled DM; acute complications such as diabetic ketoacidosis, hyperosmolar hyperglycemic state, or death, and chronic complications such as stroke, foot ulcers (diabetic foot), kidney failure, blindness, impotence, cardiovascular disease and gangrene. Uncontrolled DM has some symptoms such as frequent urination, increased thirst, increased hunger, and body weight loss [2]. Norman [3] stated that, according to the last report of WHO, number of diabetes up to 2010 was 285 million and will be 438 million at 2030 worldwide. Bailey and Day [4] reported that, there are three main types of DM; type 1 is called insulin-dependent diabetes mellitus (IDDM) or juvenile diabetes, in which the insulin secretion is completely stopped due to unknown reasons; type 2 is called non-insulin-dependent diabetes mellitus (NIDDM) or adultonset diabetes, in which the sufficient amount of insulin does not deliver to the blood due to failure of cell receptors-insulin contact. The main reason of type 2 is excessive obesity; and the last type is called gestational diabetes that associated with pregnancy without previous history of diabetes. Moreover, there are other uncommon types of DM; prediabetes in which the blood glucose level is increased but did not reach to type 2 level. Nevertheless, prediabetes may be developed to type 2. Another uncommon type of DM called latent autoimmune diabetes of adults (LADA), which be latent in the adult and then developed to type 1 . Sometimes LADA is misdiagnosed as having type 2 of DM. Type 3 of diabetes is called Alzheimer's disease in which insulin resistance by the brain is present [5]. A non-diabetic person has a normal level of blood glucose ranged from 80 to $120 \mathrm{mg} / \mathrm{dl}$. On the other hand, the normal level of blood glucose with a diabetic person is up to $180 \mathrm{mg} / \mathrm{dl}$ [6].

One of the antidiabetic approaches related to DM type 2 is an inhibition of starch hydrolyzing enzymes like $\alpha$-amylase and $\alpha$ glucosidase [7], which responsible for the liberation of disaccharides and glucose monomers respectively [8]. Alpha-glucosidase (EC3.2.1.20) is a starch hydrolyzing enzyme that catalyzes splitting of disaccharides and oligosaccharides and liberation of glucose monomers in the small intestine [9]. Therefore, all inhibitors of this enzyme are antidiabetic agents which aid in the control of the blood glucose level. Among of $\alpha$-glucosidase inhibitors, acarbose, voglibose, and miglitol. Acarbose and voglibose are not absorbed from the intestine and excreted through the faecal route, so they have poor bioavailability; however, miglitol is completely absorbed from the upper part of the intestine and excreted by the kidneys [10]. Although poor bioavailability of acarbose, it has many benefits including body weight loss, blood pressure adjustment, protection against heart diseases, and reduction of hypertriglyceridemia [11].

Acarbose is oral antidiabetic pharmaceutical product constituted of $\alpha$ glucosidase and $\alpha$-amylase inhibitors produced by Actinoplanes utahensis $[12,13]$. Voglibose is similar to acarbose, but it has only $\alpha-$ glucosidase inhibitor as a single active ingredient that produced by 
Streptomyces hygroscopicus-limoneus $[14,15]$. Valienamine is a precursor of voglibose produced by Streptomyces calvus $[16,17]$, and adiposin-1, and trestatin-B produced by Streptomyces dimorphogenes $[18,19]$. Although the high antidiabetic effect of these products, some adverse effects are found such as a headache, insomnia, vomiting, flatulence, and diarrhea [20]. Fortunately, the genetic exchange between the endophytic microbes and their antidiabetic hosts of medicinal plants plays an important role in the microbial production of antidiabetic agents; hence, the $\alpha$-glucosidase inhibitor can be produced by endophytic microbes of antidiabetic medicinal plants [21-23]. This study aims to improve the activity and stability of $\alpha$-glucosidase inhibitor that produced by marine actinomycetes.

\section{MATERIALS AND METHODS}

\section{Chemicals and reagents}

The sigma company was the single source of the following chemicals:

- Soluble starch, potassium nitrate, and dipotassium hydrogen orthophosphate.

- Calcium carbonate, magnesium sulphate, sodium chloride.

- Bacteriological agar.

- The alpha-glucosidase enzyme, $p$-nitrophenyl- $\alpha$-d-glucopyranoside, and acarbose.

- Iodine solution and magnesium chloride.

- Forward primer 5'-AGAGTTTGATCCTGGCTCAG-3'.

- Reverse primer 5'-AAGGAGGTGATCCAGCC-3'.

- Master Mix.

- Chloroform, phenol, and ethanol.

- RNase, TE buffer, proteinase K, and DNA ladder.

- Sodium dodecyl sulphate.

- Diethyl-aminoethyl-cellulose and sephadex G 200.

- Polyacrylamide gel.

- Folin reagent, copper sulphate, and bovine serum albumin.

- Streptomycin and amoxicillin powder.

- Tryptone, peptone, glycerol, and tyrosine.

- Yeast, malt, and oat extracts.

- Czapek's agar medium.

- Xanthin and esculin.

- Set of sugars.

- Set of amino acids.

- A mixture of L and meso-Diaminopimelic acid.

\section{Methodology}

\section{Isolation of marine actinomycetes}

The sediment samples of the Red Sea were collected in sterile plastic bags which preserved at $4{ }^{\circ} \mathrm{C}$, and then transported to the laboratory. All samples were dried in the air at room temperature for overnight. Isolation of marine actinomycetes was carried out on starch nitrate agar contained $10 \% \mathrm{NaCl}$ by serial dilution method [24]. All strains were purified, subcultured, and maintained on the slants of the same medium and preserved at $4{ }^{\circ} \mathrm{C}$.

\section{Screening test}

All strains of marine actinomycetes were qualitatively screened to inhibit the starch hydrolyzing enzymes included $\alpha$-glucosidase. All of them were grown on starch nitrate broth contained $10 \% \mathrm{NaCl}$, and then incubated with shaking at $30{ }^{\circ} \mathrm{C}$ and $160 \mathrm{rpm}$ for $14 \mathrm{~d}$. The suspension of each strain was centrifuged at $5000 \mathrm{xg}$ for $10 \mathrm{~min}$. The pellet was discarded, but the supernatant was pooled and filtered twice through the filter paper (Whatman No.1) to obtain the cell-free extract. The procedure was conducted as the following: There 3 clear glass test tubes were used with each cell-free extract; each tube contained $5 \mathrm{ml}$ of starch solution. The first tube (a) was supplemented with $1 \mathrm{u} / \mathrm{ml}$ of $\alpha$-glucosidase enzyme as a negative control, while the second tube (b) was supplemented with $1 \mathrm{u} / \mathrm{ml}$ of $\alpha$-glucosidase and 1 $\mathrm{mg} / \mathrm{ml}$ of acarbose ( $\alpha$-glucosidase inhibitor) (Sigma http://www, chemicalinfo. com/DWCP) as a positive control, and the third tube (c) was supplemented with $1 \mathrm{u} / \mathrm{ml}$ of $\alpha$-glucosidase and $1 \mathrm{ml}$ of cell-free extract. All tubes were left at room temperature for $10 \mathrm{~min}$, and then incubated at $37{ }^{\circ} \mathrm{C}$ for $3 \mathrm{~h}$. Starch hydrolysis was detected in all tubes by using iodine solution. The blue color was absent in the tube (a) due to complete starch hydrolysis via $\alpha$-glucosidase activity; while, the dark blue color was present in the tube (b) due to complete inhibition of $\alpha$-glucosidase activity via acarbose ( $\alpha$-glucosidase inhibitor). The ability of test organism to inhibit $\alpha$-glucosidase or not was clearly determined according to the observation in tube (c); where, absence of blue color is a negative result; while, presence of dark blue color is a positive result. All tubes (c) of positive results were further incubated at $37^{\circ} \mathrm{C}$ and examined each $24 \mathrm{~h}$. The most potent strain was selected according to the dark blue color which remained a longest period at 37 ${ }^{\circ} \mathrm{C}[25]$.

\section{Assay of $\alpha$-glucosidase inhibition}

The screening test was further conducted by quantitative method. The activity of $\alpha$-glucosidase inhibitor was measured according to Anam $e t$ al. [25]; where $\alpha$-glucosidase $(0.75 \mathrm{u} / \mathrm{ml})$ was dissolved in $0.1 \mathrm{M}$ phosphate buffer $\mathrm{pH}$ 7.0. Also, $p$-nitrophenyl- $\alpha$-d-glucopyranoside $(20$ mmol) was dissolved in $0.1 \mathrm{M}$ phosphate buffer $\mathrm{pH}$ 7.0. The reaction mixture was prepared by adding $125 \mu \mathrm{l}$ of $p$-nitrophenyl- $\alpha$-dglucopyranoside, $240 \mu \mathrm{l}$ of $0.1 \mathrm{M}$ phosphate buffer $\mathrm{pH} 7.0$ and $10 \mu \mathrm{l}$ sample, and then incubated at $37^{\circ} \mathrm{C}$ for $5 \mathrm{~min}$, and then $125 \mu \mathrm{l}$ of $\alpha$ glucosidase were added and incubated for $15 \mathrm{~min}$ at $37^{\circ} \mathrm{C}$. The reaction was stopped by addition of $500 \mu \mathrm{l}$ sodium carbonate. The reaction product is $p$-nitrofenol which was measured colourimetrically at $400 \mathrm{~nm}$. As a comparison, we used $1 \mathrm{mg} / \mathrm{ml}$ solution of acarbose. This experiment has been repeated at different incubation periods of cell-free extract of each strain to exact determine the stability of each inhibitor. The activity of $\alpha$-glucosidase inhibitory protein was determined by the following equation:

$$
\text { Inhibition }(\%)=\frac{A c-(A s-A b)}{A c \times 100}
$$

(Ac: absorbance of control, $A b$ : absorbance of background, $A s$ : absorbance of the sample).

\section{Identification of actinomycete isolate}

\section{Classical techniques}

The most potent actinomycete strain $\mathrm{AD}-7$ was identified by determination of morphological, physiological, and cultural characteristics according to Shirling and Gottlieb [26]. Inorganic salt starch agar (ISP-4) was used for cultivation and characterization of actinomycete strain by scanning electron microscopy.

\section{DNA extraction}

Actinomycete isolate was inoculated aseptically in $250 \mathrm{ml}$ Erlenmeyer flask contained $30 \mathrm{ml}$ of starch nitrate broth, and then incubated with shaking at $30^{\circ} \mathrm{C}$ and $160 \mathrm{rpm}$ for $14 \mathrm{~d}$. The bacterial suspension was centrifuged at $10000 \mathrm{xg}$ for $10 \mathrm{~min}$. The supernatant was discarded, and only $0.1 \mathrm{~g}$ of precipitated mycelia were transferred to sterile porcelain dish and crushed with liquid nitrogen. The crushed mycelia were transferred to clear tube containing $500 \mu \mathrm{l}$ of TE buffer supplemented with lysozyme $(20 \mathrm{mg} / \mathrm{ml})$. The tube was incubated at $37^{\circ} \mathrm{C}$ for $30 \mathrm{~min}$, and then supplemented with $20 \mu \mathrm{l}$ of $10 \%$ SDS (w/v) and $20 \mu$ of proteinase $\mathrm{K}$, and then incubated at $55^{\circ} \mathrm{C}$ for $30 \mathrm{~min}$. The lysate was cooled down and extracted once with an equal volume of phenol: chloroform solution $(\mathrm{v} / \mathrm{v} 1: 1)$ at $10000 \mathrm{xg}$ for $5 \mathrm{~min}$. The aqueous phase was transferred carefully to clear tube and DNA was precipitated by adding $70-90 \%$ ethanol and keeping at- $20{ }^{\circ} \mathrm{C}$ for 30 min. The pellet was formed by centrifuging at $10000 \mathrm{xg}$ for $10 \mathrm{~min}$. The pellet was washed twice with $90 \%$ ethanol and dissolved the pellet in TE buffer [27]. 


\section{PCR technique}

Polymerase chain reaction (PCR) technique was used to amplify $16 \mathrm{~S}$ rRNA gene in a thermocycler (Perkin Elmer Cetus Model 480) by using the universal primer; the forward primer 5'-AGAGTTTGATCCTGGCTCAG-3' and the reverse primer 5'-AAGGAGGTGATCCAGCC-3' [28]. PCR reaction was performed in a total volume of $25 \mu \mathrm{l}$ containing: $2.5 \mu \mathrm{l}$ PCR buffer, $1.5 \mathrm{mmol} \mathrm{MgCl}_{2}, 200 \mu \mathrm{M}$ dNTPs, 1 u Taq DNA polymerase (Ampli Taq, Perkin-Elmer), $2.5 \mu \mathrm{l}$ of $10 p$-mol each primer and $2.5 \mu \mathrm{l}$ of the extracted bacterial DNA and the volume was completed to $25 \mu \mathrm{l}$ using sterile distilled $\mathrm{H}_{2} \mathrm{O}$. PCR reaction conditions were approached as; one cycle of $94{ }^{\circ} \mathrm{C}$ for 5 min followed by 35 cycles; each cycle consists of $94^{\circ} \mathrm{C}$ for $1 \mathrm{~min}, 55^{\circ} \mathrm{C}$ for $1 \mathrm{~min}, 72{ }^{\circ} \mathrm{C}$ for $90 \mathrm{~s}$. and a final extension step at $72{ }^{\circ} \mathrm{C}$ for $5 \mathrm{~min}$. The PCR product $(1500 \mathrm{bp})$ was directly sequenced by a BigDye terminator cycle sequencing kit (PE Applied Biosystems, Foster City, CA, USA) on an ABI 310 automated DNA sequencer using both the reverse and forward primers (Applied Biosystems, Foster City, CA, USA).

\section{Optimization study}

\section{Effect of incubation period}

There ten Erlenmeyer flasks ( $250 \mathrm{ml}$ ) contained $100 \mathrm{ml}$ of starch nitrate broth at $\mathrm{pH} 7.2$ were inoculated by equal inoculum of mutant actinomycete isolate $\mathrm{AD}-7$, and then incubated with shaking at $30^{\circ} \mathrm{C}$ and $160 \mathrm{rpm}$ for different incubation periods $(2,4,6,8,10,12,14,16,18$, and $20 \mathrm{~d}$ ). The antidiabetic activity was measured as mentioned above.

\section{Effect of incubation temperature}

There ten Erlenmeyer flasks $(250 \mathrm{ml})$ contained $100 \mathrm{ml}$ of starch nitrate broth at $\mathrm{pH} 7.2$ were inoculated by equal inoculum of mutant actinomycete isolate AD-7, and then incubated with shaking at 160 rpm for different incubation temperature $(22,24,26,28,30,32,34$, 36,38 , and $40^{\circ} \mathrm{C}$ ) for $14 \mathrm{~d}$. The antidiabetic activity was measured as mentioned above.

\section{Effect of initial $\mathrm{pH}$ values}

There ten Erlenmeyer flasks $(250 \mathrm{ml})$ contained $100 \mathrm{ml}$ of starch nitrate broth. Each medium was adjusted at definite $\mathrm{pH}(5,5.5,6$, $6.5,7,7.5,8,8.5,9$, and 9.5). All flasks were inoculated by an equal inoculum of mutant actinomycete isolate AD-7, and then incubated with shaking at $160 \mathrm{rpm}$ and $30^{\circ} \mathrm{C}$ for $14 \mathrm{~d}$. The antidiabetic activity was measured as mentioned above.

\section{Effect of agitation speed}

There six Erlenmeyer flasks $(250 \mathrm{ml})$ contained $100 \mathrm{ml}$ of starch nitrate broth at $\mathrm{pH} 7.2$ were inoculated by equal inoculum of mutant actinomycete isolate $\mathrm{AD}-7$, and then incubated with shaking at $30^{\circ} \mathrm{C}$ and at different agitation speeds $(120,140,160,180,200$, and $220 \mathrm{rpm})$ for $14 \mathrm{~d}$. The antidiabetic activity was measured as mentioned above.

\section{Effect of inoculum size}

There ten Erlenmeyer flasks ( $250 \mathrm{ml}$ ) contained $100 \mathrm{ml}$ of starch nitrate broth at $\mathrm{pH} 7.2$ were inoculated by different inocula of mutant actinomycete isolate AD-7 (50, 100, 150, 200, 250, 300, 350, 400, 450, and $500 \mu \mathrm{l}$ ), and then incubated with shaking at $30^{\circ} \mathrm{C}$ and $160 \mathrm{rpm}$ for $14 \mathrm{~d}$. The antidiabetic activity was measured as mentioned above.

\section{Purification of $\alpha$-glucosidase inhibitory protein}

The batch of starch nitrate broth (2 l) at pH 8.5 was inoculated by $300 \mu \mathrm{l}\left(10^{6} \mathrm{cfu} / \mathrm{ml}\right)$ of the mutant actinomycete isolate AD-7, and then incubated with shaking at $30^{\circ} \mathrm{C}$ and $160 \mathrm{rpm}$ for $14 \mathrm{~d}$. After the incubation period, the bacterial suspension was centrifuged at 5000 $\mathrm{xg}$ for $10 \mathrm{~min}$. The pellet was discarded and supernatant contained $\alpha$-glucosidase inhibitory protein was filtered through filter paper (Whatman No.1) to obtain clear cell-free extract. The cell-free extract was sequentially supplemented with different concentrations of saturated ammonium sulfate (10 to $90 \%$ ). At each concentration, the mixture was preserved at $4{ }^{\circ} \mathrm{C}$ for $2 \mathrm{~h}$. The mixture was centrifuged at $5000 \mathrm{xg}$ for $20 \mathrm{~min}$ at $4{ }^{\circ} \mathrm{C}$. The supernatant was discarded; while the precipitate was dissolved in $10 \mathrm{ml}$ phosphate buffer ( $\mathrm{pH}$ 8.5). The total protein content of the cell-free extract (control) and of each fraction contained precipitated proteins was estimated according to Lowery et al. [29]. Ion-exchange column chromatography using di-ethyl-amino-ethyl cellulose as a resin was conducted according to Dale and Smith [30]. The active fractions were pooled and passed through sephadex G 200 to obtain purified protein according to Andrews [31].

\section{Separation of $\alpha$-glucosidase inhibitory protein}

The molecular weight of $\alpha$-glucosidase inhibitory protein was determined by using sodium dodecyl sulphate-polyacrylamide gel electrophoresis (SDS-PAGE) according to Blackshear [32]

\section{RESULTS AND DISCUSSION}

\section{Isolation of marine actinomycetes}

There 55 marine actinomycete strains were isolated from the sediment samples of the Red Sea. The isolation was carried out on starch nitrate agar contained $10 \% \mathrm{NaCl}$. All strains were picked up, purified, subcultured, and then preserved at $4{ }^{\circ} \mathrm{C}$. Many therapeutic compounds including antidiabetics are highly producing by marine microorganisms [33], especially marine actinomycetes that usually isolated from soils or sediments of the sea [34]. Although marine actinomycetes are economic medical bacteria due to their highly production for medical substances particularly antimicrobial agents [35], they are not widely used as antidiabetic producers [36].

\section{Screening test}

These strains were screened qualitatively to inhibit starch hydrolysis via inactivation of the $\alpha$-glucosidase enzyme. Both of $p$ nitrophenyl- $\alpha$-d-glucopyranoside and acarbose were used as a substrate and an enzyme inhibitor respectively. The screening test resulted in only 7 antidiabetic strains are present; however, the highest activity and stability of an inhibitor were observed in the cell-free extract of the strain AD-7 (fig. 1a). Iodine solution was used as a reagent to detect the starch hydrolysis. So, the dark blue color that clearly appeared in the tube (a) referred to retarded starch hydrolysis by the action of the cell-free extract contained an $\alpha$ glucosidase inhibitor. On the other hand, the white color in the tube (b) referred to complete starch hydrolysis by the action of the $\alpha$ glucosidase enzyme. The dark blue color in the tube (a) remained at fifth day of incubation at $37^{\circ} \mathrm{C}$, and then disappeared gradually (fig. 1b). Ganesan et al. [37] reported that there 4 strains among 30 ones were found have the ability to produce $\alpha$-glucosidase inhibitor.
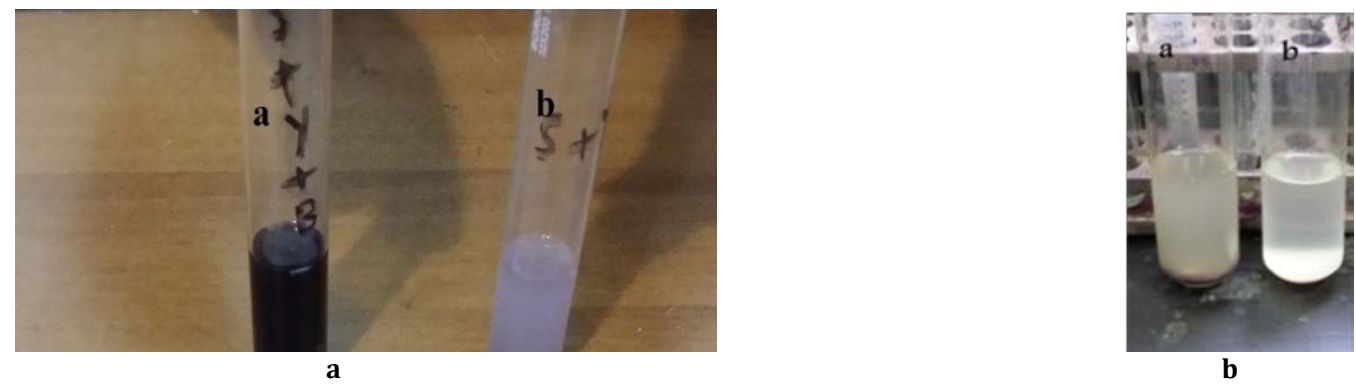

Fig. 1: (a) Tube (a) inhibition of $\alpha$-glucosidase activity by cell free extract of strain AD- 7 up to fifth day of incubation at $37^{\circ} \mathrm{C}$; tube (b) hydrolyzed starch by $\alpha$-glucosidase activity. (b) tube (a) disappearance of dark blue color after fifth day of incubation at $37^{\circ} \mathrm{C}$ due to degradation of $\alpha$-glucosidase inhibitor in the cell free extract of strain AD-7; tube (b) hydrolyzed starch by $\alpha$-glucosidase activity, $n=1$ 


\section{Assay of $\alpha$-glucosidase inhibition}

The quantitative screening test was carried out for all strains, where the activity of an inhibitor was measured colourimetrically at $400 \mathrm{~nm}$ (table 1). Furthermore, the stability of $\alpha$-glucosidase inhibitor was determined, where the more stable inhibitor was being active at the longest incubation period at $37{ }^{\circ} \mathrm{C}$. The results of qualitative and quantitative tests were conformed with each other, where the same 7 antidiabetic strains were present; AD-4, AD-7, AD-16, AD-24, AD-31, AD-33, and AD40 strains were found has $2.3 \%$ at $3^{\text {rd }} \mathrm{d}, 4.2 \%$ at $5^{\text {th }} \mathrm{d}, 1.8 \%$ at $7^{\text {th }} \mathrm{d}, 1.0 \%$ at $4^{\text {th }} \mathrm{d}, 3.2 \%$ at $5^{\text {th }} \mathrm{d}, 3.0 \%$ at $5^{\text {th }} \mathrm{d}$, and $2.7 \%$ at $6^{\text {th }} \mathrm{d}$ respectively. Accordingly, the strain AD-7 was considered the most potent due to the highest activity and more stability of $\alpha$-glucosidase inhibitor, followed by AD-31, AD-33, AD-40, AD-4, AD-16, and AD-24 strains. Imada and Simidu [38] stated that, out of 30 strains of actinomycetes, there only 7 strains were found have the ability to decrease the blood glucose level in the rats by inhibition of $\alpha$-glycosidase, while the others did not exhibit any activity. The most potent strain was symbolized as PSG-22, which had a highest in vitro and in vivo $\alpha$-glucosidase inhibition activity. In vitro $\alpha$ glucosidase inhibition activity was showed with only 6 strains.

Table 1: Assay the activity of the $\alpha$-glucosidase inhibitor

\begin{tabular}{|c|c|c|c|c|c|c|c|c|c|c|}
\hline \multirow[t]{2}{*}{ Strain No. } & \multicolumn{10}{|c|}{ Inhibition activity (\%)/d } \\
\hline & $1^{\text {st }}$ & $2^{\text {nd }}$ & $3^{\text {rd }}$ & $4^{\text {th }}$ & $5^{\text {th }}$ & $6^{\text {th }}$ & $7^{\text {th }}$ & $8^{\text {th }}$ & $9^{\text {th }}$ & $10^{\text {th }}$ \\
\hline $\mathrm{AD}(1-3)$ & 0.0 & 0.0 & 0.0 & 0.0 & 0.0 & 0.0 & 0.0 & 0.0 & 0.0 & 0.0 \\
\hline AD-4 & $1.2 \pm 0.10$ & $1.8 \pm 0.15$ & $2.3 \pm 0.15$ & $2.0 \pm 0.12$ & $1.6 \pm 0.11$ & $1.2 \pm 0.10$ & $0.7 \pm 0.08$ & $0.5 \pm 0.05$ & $0.3 \pm 0.02$ & 0.0 \\
\hline $\mathrm{AD}(5-6)$ & 0.0 & 0.0 & 0.0 & 0.0 & 0.0 & 0.0 & 0.0 & 0.0 & 0.0 & 0.0 \\
\hline AD-7 & $1.7 \pm 0.11$ & $2.4 \pm 0.15$ & $3.1 \pm 0.18$ & $3.7 \pm 0.21$ & $4.2 \pm 0.25$ & $3.4 \pm 0.20$ & $2.8 \pm 0.17$ & $2.1 \pm 0.15$ & $1.5 \pm 0.12$ & $0.9 \pm 0.10$ \\
\hline $\mathrm{AD}(8-15)$ & 0.0 & 0.0 & 0.0 & 0.0 & 0.0 & 0.0 & 0.0 & 0.0 & 0.0 & 0.0 \\
\hline AD-16 & $0.1 \pm 0.01$ & $0.3 \pm 0.01$ & $0.5 \pm 0.02$ & $0.8 \pm 0.03$ & $1.4 \pm 0.11$ & $1.6 \pm 0.11$ & $1.8 \pm 0.12$ & $1.2 \pm 0.10$ & $0.6 \pm 0.02$ & 0.0 \\
\hline $\mathrm{AD}(17-23)$ & 0.0 & 0.0 & 0.0 & 0.0 & 0.0 & 0.0 & 0.0 & 0.0 & 0.0 & 0.0 \\
\hline AD-24 & $0.1 \pm 0.01$ & $0.4 \pm 0.01$ & $0.7 \pm 0.03$ & $1.0 \pm 0.08$ & $0.5 \pm 0.05$ & $0.2 \pm 0.02$ & 0.0 & 0.0 & 0.0 & 0.0 \\
\hline $\mathrm{AD}(25-30)$ & 0.0 & 0.0 & 0.0 & 0.0 & 0.0 & 0.0 & 0.0 & 0.0 & 0.0 & 0.0 \\
\hline$A D-31$ & $0.3 \pm 0.01$ & $0.7 \pm 0.03$ & $1.5 \pm 0.11$ & $2.8 \pm 0.15$ & $3.2 \pm 0.20$ & $2.1 \pm 0.15$ & $1.4 \pm 0.11$ & $0.8 \pm 0.07$ & $0.3 \pm 0.02$ & 0.0 \\
\hline AD-32 & 0.0 & 0.0 & 0.0 & 0.0 & 0.0 & 0.0 & 0.0 & 0.0 & 0.0 & 0.0 \\
\hline AD-33 & $0.7 \pm 0.03$ & $1.3 \pm 0.15$ & $1.9 \pm 0.18$ & $2.6 \pm 0.19$ & $3.0 \pm 0.23$ & $2.1 \pm 0.18$ & $1.6 \pm 0.15$ & $1.1 \pm 0.11$ & $0.4 \pm 0.01$ & 0.0 \\
\hline $\mathrm{AD}(34-39)$ & 0.0 & 0.0 & 0.0 & 0.0 & 0.0 & 0.0 & 0.0 & 0.0 & 0.0 & 0.0 \\
\hline$A D-40$ & $0.3 \pm 0.01$ & $0.5 \pm 0.02$ & $0.8 \pm 0.04$ & $1.7 \pm 0.11$ & $2.3 \pm 0.19$ & $2.7 \pm 0.22$ & $2.0 \pm 0.18$ & $1.2 \pm 0.10$ & $0.5 \pm 0.02$ & 0.0 \\
\hline $\mathrm{AD}(41-55)$ & 0.0 & 0.0 & 0.0 & 0.0 & 0.0 & 0.0 & 0.0 & 0.0 & 0.0 & 0.0 \\
\hline
\end{tabular}

$\mathrm{n}=2 ; \pm \mathrm{SD}$

\section{Identification of actinomycete isolate}

The actinomycete strain AD-7 as a most potent antidiabetic one was identified classically according to Shirling and Gottlieb [26], where cultural characteristics were determined as shown in table 2. The cultural characteristics were determined by using seven growth media; tryptone-yeast extract agar, yeast-malt extract agar, oatmeal extract agar, inorganic salts starch agar, glycerol asparagine agar, peptone yeast extract iron agar and tyrosine agar media. The good growth with the light gray color of aerial mycelia and light gray yellowish-brown color of substrate mycelia and diffusible pigments were observed on tryptone-yeast extract agar, yeast-malt extract agar, and inorganic salts starch agar media. The oat-meal extract agar medium was found has a moderate growth with the light gray color of aerial mycelia, the light yellowish-brown color of substrate mycelia and light gray yellowish-brown color of diffusible pigments. The peptone yeast extracts iron agar medium was found has a moderate growth with the light gray color of aerial mycelia and light gray yellowish-brown color of both substrate mycelia and diffusible pigments. The poor growth with the light gray color of aerial mycelia and light gray yellowish-brown color of both substrate mycelia and diffusible pigments were observed on glycerol asparagine agar medium. The poor growth with the light gray color of aerial mycelia the light yellowish-brown color of substrate mycelia and light gray yellowish-brown color of diffusible pigments were observed on tyrosine agar medium.

The morphological, biochemical, and physiological characteristics were determined as shown in table 3 . There 2 growth media were used in the illustration of light microphotograph (fig. 2a) and electron micrograph (fig. 2b); glycerol asparagine agar [39] and starch nitrate agar [24] respectively. The spore chain was found has an open hook shape that constructed from ellipsoidal spores which have a smooth surface. The motility of strain AD-7 had not been observed. The cell wall hydrolyses proved that LL-Diaminopimelic acid (LL-DAP) was present; however, the sugar pattern was not detected.

Table 2: Cultural characteristics of AD-7 strain

\begin{tabular}{|c|c|c|c|c|}
\hline Media & Growth rate & Aerial mycelia & Substrate mycelia & Diffusible pigment \\
\hline Tryptone yeast extract agar & Good & $264 \mathrm{lg}$ & 79 lgyYBr & 79 lgyYBr \\
\hline Yeast-malt extract agar & Good & $263 \mathrm{lg}$ & 79 lgyYBr & 79 lgyYBr \\
\hline Oat-meal extract agar & Moderate & $264 \mathrm{lg}$ & $76 \mathrm{lYBr}$ & 79 lgyYBr \\
\hline Inorganic salts starch agar & Good & $264 \mathrm{lg}$ & 79 lgyYBr & 79 lgyYBr \\
\hline Glycerol asparagine & Poor & $264 \mathrm{lg}$ & 79 lgyYBr & 79 lgyYBr \\
\hline Peptone yeast extract iron agar & Moderate & $264 \mathrm{lg}$ & 79 lgyYBr & 79 lgyYBr \\
\hline Tyrosine agar & Poor & $264 \mathrm{lg}$ & $76 \mathrm{lYBr}$ & 79 lgyYBr \\
\hline
\end{tabular}

Tyrosine agar Poor $264 \mathrm{lg}$

$\mathrm{n}=3$
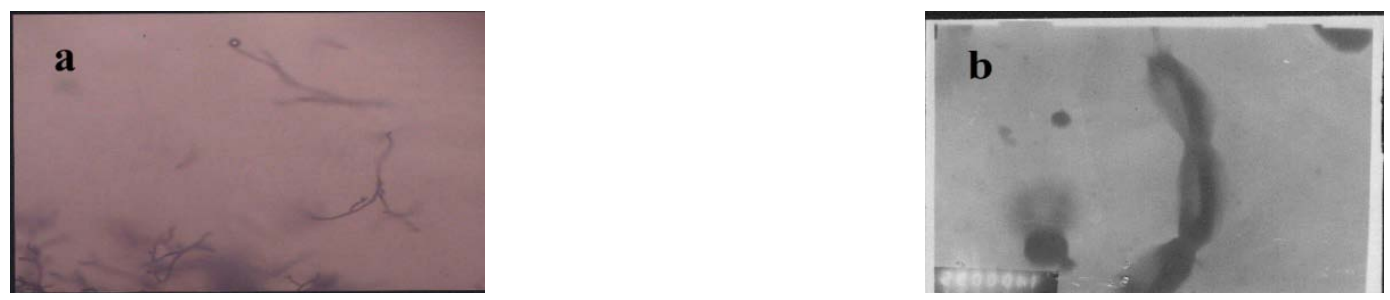

Fig. 2: (a) Microphotograph (x 1500) of actinomycete strain AD-7. (b) transmission electron micrograph (x 21000 ) of actinomycete strain AD-7, $n=4$ 
The strain AD-7 does not have the ability to produce the melanoid pigment, complete or partial reduction of nitrate, production of $\mathrm{H}_{2} \mathrm{~S}$, and degradation of xanthin and esculin. Due to the nature of the strain habitat, it had been well grown on starch nitrate agar medium contained a high concentration of sodium chloride (5-15\%). The strain AD-7 was found has a poor growth on Czapek's agar medium and high sensitivity to both of streptomycin and amoxicillin antibiotics $(50 \mu \mathrm{g} / \mathrm{ml})$. There different degrees of enzymatic activity were recorded, where cellulase and pectinase were highly produced, protease and coagulase were moderately produced; however, lipase was poorly produced and catalase was never secreted. D-glucose, Dgalactose, D-fructose, D-mannitol, Sucrose, L-arabinose, and Lrhamnose were highly utilized; while, D-xylose and raffinose were moderately utilized and meso-inositol was poorly utilized. On the other hand, L-proline and L-tyrosine were highly utilized, L- histidine, L-phenylalanine, and L-lysine were moderately utilized; however, L-alanine, L-valine, L-leucine, and L-cystiene were poorly utilized.

On the other hand, the strain AD-7 was identified by detection of the encoded 16S rRNA gene of Streptomyces bacteria using PCR technique. The DNA was extracted according to Pitcher et al. [27], and then isolated and amplified according to Weisburg et al. [28].

The gene was separated as a single band at 1500 bp by agarose gel electrophoresis (fig. 3). According to the results of classical and molecular techniques, the actinomycete strain AD-7 was identified as Streptomyces coelicolor. Bentley et al. [40] reported that the complete sequencing for the full genome of Streptomyces coelicolor proved that this bacterium is considered a powerful producer for several secondary metabolites included $\alpha$-glucosidase inhibitor.

Table 3: Morphological, biochemical and physiological characteristics of AD-7 strain

\begin{tabular}{|c|c|c|}
\hline Characteristics & Parameter & Result \\
\hline \multirow[t]{4}{*}{ Morphological } & Shape of spore chain & Open hook \\
\hline & Shape of spore & Ellipsoidal \\
\hline & Feel of spore surface & Smooth \\
\hline & Motility & Non-motile \\
\hline \multirow[t]{2}{*}{ Biochemical } & Type of DAP in the cell wall & LL-DAP \\
\hline & Sugar pattern in the cell wall & Not detected \\
\hline \multirow{16}{*}{ Physiological } & Melanoid, nitrate, and $\mathrm{H}_{2} \mathrm{~S}$ production & -ve \\
\hline & Degradation of xanthin and esculin & -ve \\
\hline & $\mathrm{NaCl}$ tolerance $(5-15 \%)$ & +++ \\
\hline & Growth on Czapek's agar & + \\
\hline & Streptomycin resistance $(50 \mu \mathrm{g} / \mathrm{ml})$ & Sensitive \\
\hline & Amoxicillin resistance $(50 \mu \mathrm{g} / \mathrm{ml})$ & Sensitive \\
\hline & Protease and coagulase production & ++ \\
\hline & Lipase production & + \\
\hline & Cellulase and pectinase production & +++ \\
\hline & Catalase production & -ve \\
\hline & D-glucose, D-galactose, D-fructose, D-mannitol, Sucrose, L-arabinose, and L-rhamnose & +++ \\
\hline & D-xylose and Raffinose & ++ \\
\hline & meso-Inositol & + \\
\hline & L-valine, L-alanine, L-leucine, and L-cysteine & + \\
\hline & L-histidine, L-phenylalanine, and L-lysine & ++ \\
\hline & L-proline and L-tyrosine & +++ \\
\hline
\end{tabular}

$\mathrm{n}=5$; lg is light gray; lgyYBr is light gray yellowish brown; IYBr is light yellowish brown; -ve is not produced; +is poor; ++is moderate; +++is good

Table 4: Assay the activity of an $\alpha$-glucosidase inhibitor of mutant AD-7 strain

\begin{tabular}{|c|c|c|c|c|c|c|c|c|c|c|c|}
\hline \multirow[t]{2}{*}{ Fc } & \multirow[t]{2}{*}{ Ep (s) } & \multicolumn{10}{|c|}{ Inhibition activity $(\%) / d$} \\
\hline & & $1^{\text {st }}$ & $2^{\text {nd }}$ & $3^{\text {rd }}$ & $4^{\text {th }}$ & $5^{\text {th }}$ & $6^{\text {th }}$ & $7^{\text {th }}$ & $8^{\text {th }}$ & $9^{\text {th }}$ & $10^{\text {th }}$ \\
\hline 1 & 5.0 & $2.3 \pm 0.18$ & $3.0 \pm 0.24$ & $3.7 \pm 0.26$ & $4.5 \pm 0.31$ & $3.8 \pm 0.26$ & $3.1 \pm 0.24$ & $2.3 \pm 0.18$ & $1.6 \pm 0.15$ & $1.0 \pm 0.11$ & $0.7 \pm 0.06$ \\
\hline 2 & 10 & $2.5 \pm 0.15$ & $3.4 \pm 0.26$ & $4.1 \pm 0.31$ & $4.7 \pm 0.31$ & $5.1 \pm 0.36$ & $4.5 \pm 0.31$ & $3.7 \pm 0.26$ & $3.1 \pm 0.23$ & $2.4 \pm 0.15$ & $1.8 \pm 0.18$ \\
\hline 3 & 15 & $2.1 \pm 0.18$ & $2.8 \pm 0.15$ & $3.5 \pm 0.26$ & $4.1 \pm 0.31$ & $4.7 \pm 0.31$ & $3.9 \pm 0.29$ & $3.2 \pm 0.26$ & $2.4 \pm 0.15$ & $1.8 \pm 0.18$ & $1.1 \pm 0.11$ \\
\hline 4 & 30 & $1.8 \pm 0.18$ & $2.7 \pm 0.15$ & $3.6 \pm 0.26$ & $4.2 \pm 0.31$ & $4.8 \pm 0.31$ & $4.3 \pm 0.31$ & $3.2 \pm 0.26$ & $2.6 \pm 0.15$ & $1.7 \pm 0.18$ & $1.2 \pm 0.11$ \\
\hline
\end{tabular}

$\mathrm{n}=7$; Fc is the fraction; Ep is the exposure period; $\pm \mathrm{SD}$

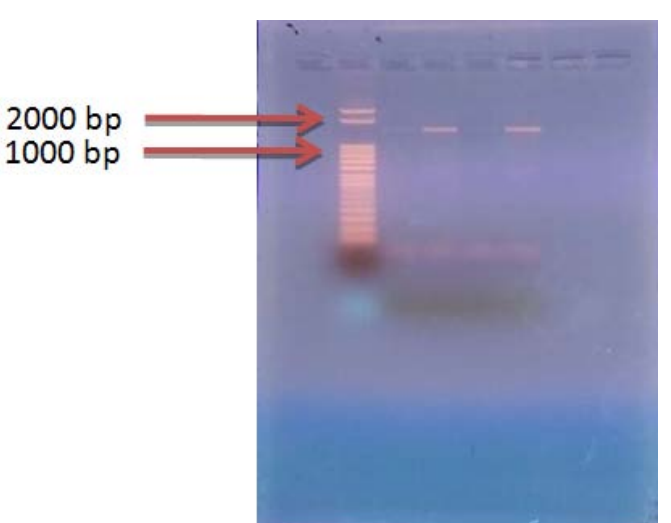

Fig. 3: Agarose gel electrophoresis of amplified 16S rRNA gene of AD-7 strain, $n=6$
The genetic improvement was carried out by using UV rays $(260$ $\mathrm{nm}$ ) that have dominated the strain AD-7 for different time periods $(5,10,15$, and $30 \mathrm{~s})$. The physical mutation showed promising results, where the improved $\alpha$-glucosidase inhibitor was gotten especially at $10 \mathrm{~s}$ of the exposure period (table 4 ).

However, there clear morphological changes were observed, where the number of colonies was inversely proportional with the exposure time, as well as, the color of aerial mycelia, substrate mycelia, and diffusible pigments was changed (fig. 4). Adepu [41] reported that, UV radiation was used to make a physical mutation for the Streptomyces gresioaurantiacus to increase $\beta$-glucosidase production. The maximum yield of an enzyme from the mutant strain was obtained within $94 \mathrm{~h}$ compared to the wild strain within 120 h. Nevertheless, we have observed that $S$. gresioaurantiacus has a high resistance to the physical mutagenesis even at $60 \mathrm{~min}$. Although a physical treatment was usually followed by a chemical one to avoid the reversible mutation [42], the mutant $S$. gresioaurantiacus was found has an irreversible physical mutation. 


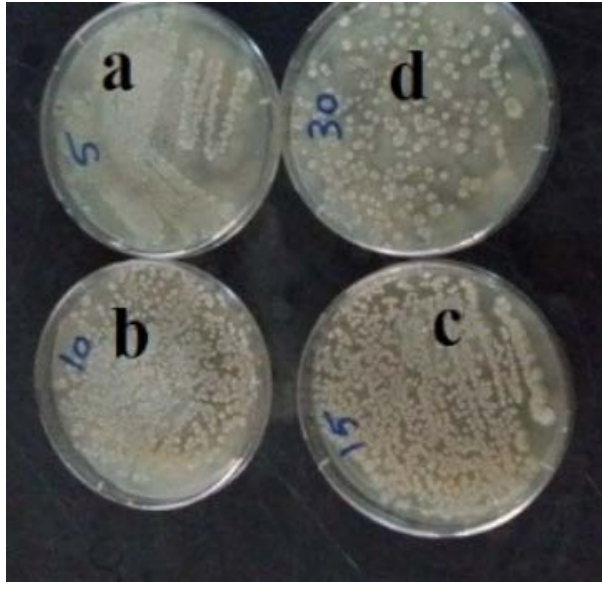

Fig. 4: Morphological changes of mutant strain on agar medium due to exposure to UV rays at different time periods: (a) $5 \mathrm{~s}$ (b) $10 \mathrm{~s}$ (c) $15 \mathrm{~s}$ (d) $30 \mathrm{~s}, \mathrm{n}=8$

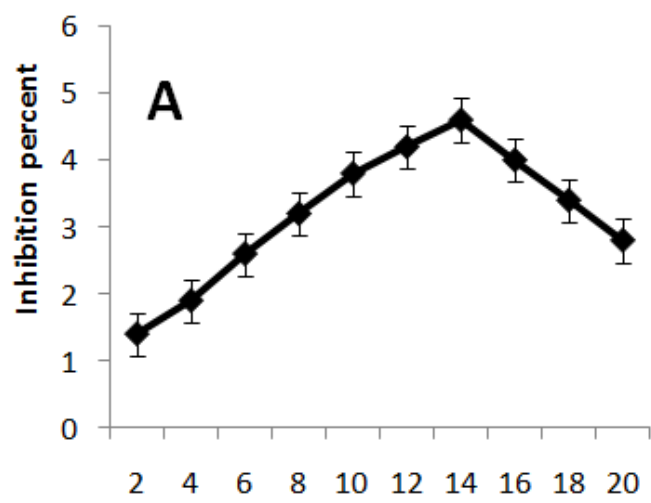

Incubation period (day)

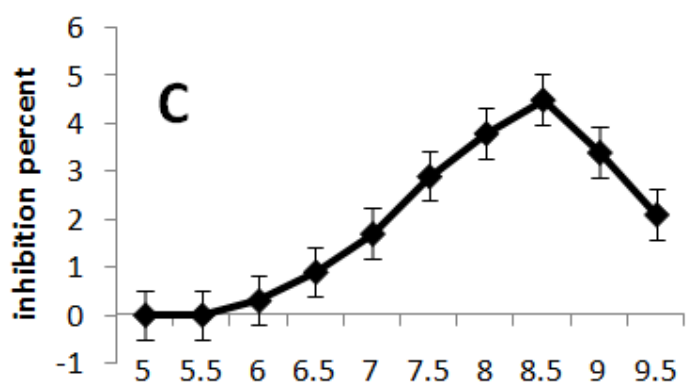

$\mathrm{pH}$ value

\section{Optimization study}

All optimum environmental factors were determined to obtain a maximum activity and stability of $\alpha$-glucosidase inhibitor that produced by a mutant strain. The best incubation periods (fig. 5A), incubation temperature (fig. 5B), pH value (fig. 5C), inoculum size (fig. 5D), and agitation speed (fig. 5E) were determined at $14 \mathrm{~d}, 30$ ${ }^{\circ} \mathrm{C}, 8.5,10^{6} \mathrm{cfu} / \mathrm{ml}(300 \mu \mathrm{l})$, and $160 \mathrm{rpm}$ respectively. Fei Ren et al. [43] stated that, the effect of pH on Streptomyces M37 growth and $\alpha$ glucosidase inhibitor production was determined, where the initial $\mathrm{pH}$ ranged from 6.5 to 8.5 . The highest dry cell weight (DCW) (21.58 $\mathrm{g} / \mathrm{l}$ ) was achieved at an initial $\mathrm{pH}$ of 7.0, and then decreased at $\mathrm{pH}$ up to 8.0 . The maximum yield of $\alpha$-glucosidase inhibitor $(173.7 \mathrm{mg} / \mathrm{l}$ DCW) was obtained at an initial $\mathrm{pH}$ of 8.0 . At $3345 \mathrm{mg} / \mathrm{l}, \alpha$ glucosidase inhibitor production was higher at an initial $\mathrm{pH}$ of 8.0, than at other initial $\mathrm{pH}$ values. At the same time, specific $\alpha$ glucosidase inhibitor production $\left(\mathrm{C}_{\max } \mathrm{mg} / \mathrm{l} \mathrm{DCW}\right)$ increased along with initial pH (in the 6.5 to 8.0 range). Accordingly, the high growth was correlated with a low initial $\mathrm{pH}$, but on the other hand, the highest activity and productivity of $\alpha$-glucosidase inhibitor were associated with a high initial $\mathrm{pH}$ value. These results were found closely related with those of Zhuge et al. [44].

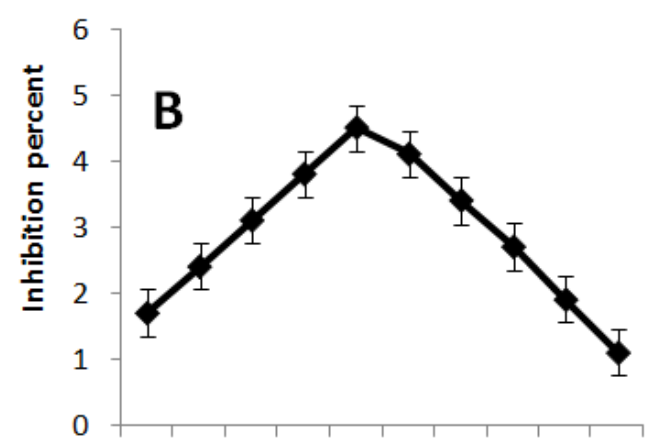

$\begin{array}{llllllllll}22 & 24 & 26 & 28 & 30 & 32 & 34 & 36 & 38 & 40\end{array}$

Incubation temperature $\left({ }^{\circ} \mathrm{C}\right)$

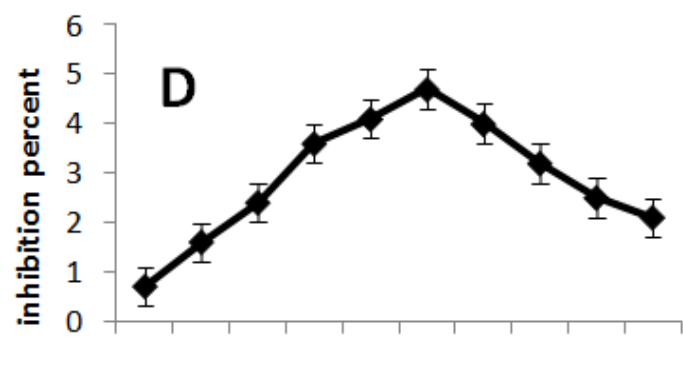

50100150200250300350400450500

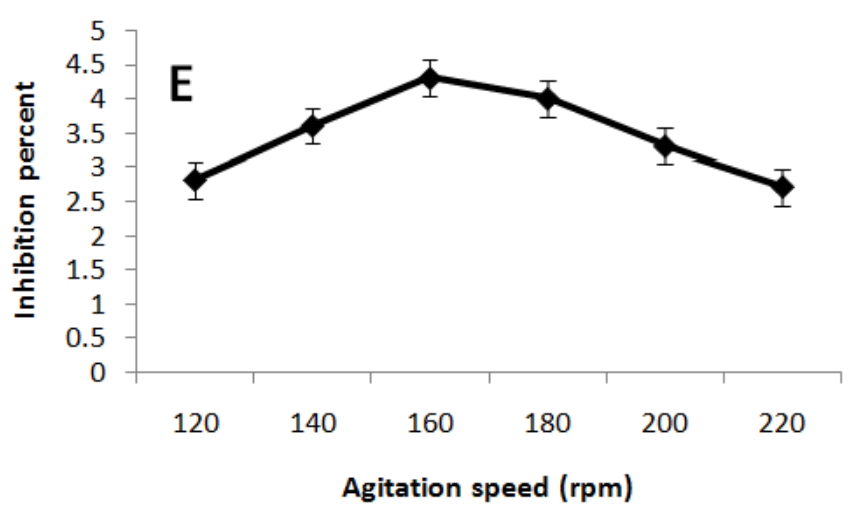

Fig. 5: Effect of different optimum environmental factors on mutant AD-7 strain, $n=9$ 


\section{Purification and separation of $\alpha$-glucosidase inhibitory protein}

Many studies which have been conducted in this field isolated and purified an intracellular $\alpha$-glucosidase inhibitor. However, the concerned $\alpha$-glucosidase inhibitor in this study is an extracellular secondary metabolite that has a peptide nature. The stepwise purification process was carried out by using diethyl-aminoethylcellulose and sephadex G 200 in an ion exchange and gel filtration column chromatography respectively. The purified protein was separated as a single band at $34 \mathrm{KDa}$ by using sodium-dodecylsulphate-polyacrylamide gel electrophoresis (fig. 6). Therefore, there is a new fact has been recorded, where there are two types of $\alpha$-glucosidase inhibitor according to the secretion site; intracellular and extracellular $\alpha$-glucosidase inhibitor.

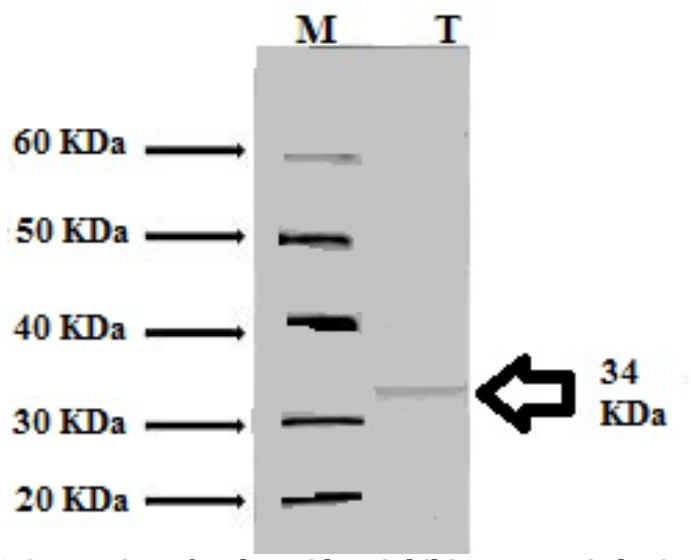

Fig. 6: Separation of $\alpha$-glucosidase inhibitory protein by SDSPAGE, $\mathrm{n}=10$

\section{CONCLUSION}

Among 55 marine actinomycete strains which isolated from the sediment samples of the Red Sea, only 7 antidiabetic strains were present included a most potent strain that symbolized AD-7, which identified by using classical and molecular techniques as $S$. coelicolor. The genetic improvement of the latter had been carried out by using UV radiations, where the more active and more stable $\alpha$-glucosidase inhibitor was obtained. All optimum environmental conditions were determined to increase the productivity of an inhibitor. Eventually, an inhibitor was purified and separated as a single band at $34 \mathrm{KDa}$.

\section{ACKNOWLEDGEMENT}

The authors thank the Chairman of National Organization for Drug Control and Research (NODCAR) for his support to this work, and also they are grateful to Head and members of Microbiology Department.

\section{AUTHORS CONTRIBUTIONS}

All the authors have contributed equally

\section{CONFLICT OF INTERESTS}

Declared none

\section{REFERENCES}

1. West IC. Radicals and oxidative stress in diabetes. Diabetes Med 2000;17:171-80.

2. Chakrabarti R, Rajagopalan R. Diabetes and insulin resistance associated disorders: disease and the therapy. Curr Sci 2002;83:1533-8.

3. Norman P. Diabetes pipeline: intense activity to meet unmet need report-overview. 2nd ed. Massachusetts (USA): Cambridge Healthtech Institute; 2010.

4. Bailey CJ, Day C. Antidiabetic drugs. Br J Cancer 2003;10:12836.
5. De la Monte SM. Type 3 diabetes is sporadic alzheimer's disease. Eur Neurol Pharmacol 2014;24:1954-60.

6. Kitabchi AE, Umpierrez GE, Miles JM, Fisher JN. Hyperglycemic crises in adult patients with diabetes. Diabetes Care 2009;32:1335-43

7. Bhosale UP, Hallale BV. Gamma radiation-induced mutations in black gram (Vigna mungo L. Hepper). Asian J Plant Sci Res 2011;1:96-100.

8. Subramanian R, Asmawi AZ, Sadikun A. In vitro alphaglucosidase and alpha-amylase enzyme inhibitory effects of Andrographis paniculata extract and andrographolide. Ambrose Bierce Project 2008;55:391-8.

9. Fatmawati S, Shimizu K, Kondo R, Ganoderol B. A potent $\alpha$ glucosidase inhibitor isolated from the fruiting body of Ganoderma lucidum. Phytomedicine 2011;18:1053-5.

10. Hanefeld M, Schaper F. The role of alpha-glucosidase inhibitors (Acarbose). In: Mogensen CE, editor. Pharmacotherapy of diabetes: new developments. 2nd ed. Springer: Boston MA; 2007. p. 143-52.

11. Chiasson JL, Robert GJ, Ramon G, Hanefeld M, Karasik A, Laakso $\mathrm{M}$, et al. Acarbose treatment and the risk of cardiovascular disease and hypertension in patients with impaired glucose tolerance the STOP-NIDDM trial. J Am Med Association 2003;290:486-94.

12. Schmidit DD, Frommer W, Junge B, Muller L, Wingender W, Truscheit E, et al. $\alpha$-glucosidase inhibitors: new complex oligosaccharides of microbial origin. Naturwissenschaften 1977;64:535-6.

13. McGown J. Out of Africa: Mysteries of access and benefit sharing. 2nd ed. Washington (USA): The Edmonds Institute; 2006.

14. De Melo EB, Gomes ADS, Carvalho I. $\alpha$-and $\beta$-glucosidase inhibitors: chemical structure and biological activity. Tetrahedron 2006;62:10277-302.

15. Kameda Y, Asano N, Yoshikawa M, Matsui K. Valienamine as an $\alpha$-glucosidase inhibitor. J Antibiot 1980;33:1575-6.

16. Mahmud T. The $\mathrm{C}_{7} \mathrm{~N}$ aminocyclitol family of natural products. Nat Prod Rep 2003;20:137-66.

17. Truscheit E, Frommer W, Junge B, Muller L, Schmidt DD, Wingender $W$. Chemistry and biochemistry of microbialglucosidase inhibitors. Angewandte Chem 1981;20:744-61.

18. Yokose K, Ogawa K, Sano T, Watanabe K, Maruyama HB, Suhara Y. New alpha-amylase inhibitor, trestatins. I. isolation, characterization and biological activities of trestatins A, B and C. J Antibiot 1983;36:1157-65.

19. Yokose K, Ogawa M, Ogawa K. New $\alpha$-amylase inhibitor, trestatins III: structure determination of new trestatin components ro 09-0766, Ro 090767 and Ro 09-0768. J Antibiot 1984;37:182-6.

20. Van de Laar FA, Lucassen PL, Akkermans RP, Van de Lisdonk EH Rutten GE, Van Weel C. Alpha-glucosidase inhibitors for patients with type 2 diabetes: results from a cochrane systematic review and meta-analysis. Diabetes Care 2005;28:154-63.

21. Morshed MA, Haque A, Rokeya B, Ali L. Anti-Hyperglycemic and lipid-lowering effect of Terminalia arjuna bark extract on streptozotocin-induced type 2 diabetic model rats. Int J Pharm Pharm Sci 2011;3:449-53.

22. Lamba HS, Bhargava CS, Thakur M, Bhargava S. Alpha glucosidase and aldolase reductase inhibitory activity in vitro and antidiabetic activity in vivo of Tribulus terrestris $\mathrm{L}$. (DUNAL). Int J Pharm Pharm Sci 2011;3:270-2.

23. Upwar N, Patel R, Waseem N, Mahobia NK. Hypoglycemic effect of methanolic extract of Berberis aristata DC stem on normal and streptozotocin-induced diabetic rats. Int J Pharm Pharm Sci 2011;3:222-4

24. Waksman SA. The actinomyces: antibiotics of actinomycetes. $2^{\text {nd }}$ ed. USA: The Williams and Wilkins company; 1961.

25. Anam K, Widharna RM, Kusrini D. $\alpha$-glucosidase inhibitor activity of Terminalia species. Int J Pharmacol 2009;5:277-80.

26. Shirling EB, Gottlieb D. Methods for characterization of Streptomyces species. Int J Syst Evol Microbiol 1996;16:313-40.

27. Pitcher DG, Saunder NA, Own RJ. Rapid extraction of bacterial genomic DNA with guanidium thiocyanate. Lett Appl Microbiol 1989;8:151-6. 
28. Weisburg WG, Barns SM, Pelletie DA, Lane DJ. 16S ribosomal DNA amplification for phylogenetic study. J Bacteriol 1991;173:697-703.

29. Lowery $\mathrm{OH}$, Rosebrough J, Farr AL, Randall RJ. Protein measurements with the folin phenol reagent. J Biol Chem 1951;193:265-75

30. Dale JW, Smith JT. The purification and properties of the $\beta$ lactamase specified by the resistance factor R-1818 in E coli and Proteus mirabilis. Biochem J 1971;123:493-500.

31. Andrews P. Estimation of the molecular weight of proteins by sephadex gel filtration. Biochem J 1964;91:222-3.

32. Blackshear PJ. Systems for polyacrylamide gel electrophoresis. Methods Enzymol 1984;104:237-55.

33. Zhang L, Rong A, Wang J, Sun N, Zhang S, Hu J, et al. Exploring novel bioactive compounds from marine microbes. Curr Opin Microbiol 2005;8:276-81.

34. Imada C. Enzyme inhibitors and other bioactive compounds from marine actinomycetes. Antonie Van Leeuwenhoek 2005;87:59-63.

35. Lazzarini A, Cavaletti L, Toppo G, Marinelli F. Rare genera of actinomycetes as potential producers of new antibiotics. Antonie Van Leeuwenhoek 2000;78:399-405.

36. Siva KK, Sahu MK, Kathiresan K. Isolation of actinomycetes from the mangrove environment of the South-East Coast of India. Ecol Environ Conserv 2005;11:355-7.

37. Ganesan S, Raja S, Sampathkumar P, Sivakumar K, Thangaradjou $\mathrm{T}$. Isolation and screening of $\alpha$-glucosidase enzyme inhibitor producing marine actinobacteria. Afr J Microbiol Res 2011;5:3437-245.

38. Imada C, Simidu U. Culture conditions for an $\alpha$-amylase inhibitor-producing marine actinomycetes and production of the inhibitor "Amylostreptin". Nippon Suisan Gakk 1992;58:2169-74.

39. Pridham TG, Lyons JR. Streptomyces albus (Rossi-Doria) Waksman and Henric: a taxonomic study of strains labelled Streptomyces albus. J Bacteriol 1961;81:431-41.

40. Bentley SD, Chater KF, Cerdeno-Tarraga AM, Challis GL Thomson NR, James $\mathrm{K}$, et al. Complete genome sequence of the model actinomycete Streptomyces coelicolor A3. Nature 2002;417:141-7.

41. Adepu KK. UV mutagenesis treatment for improved production of endoglucanase and $\beta$-Glucosidase from newly isolated thermotolerant actinomycetes, Streptomyces gresioaurantiacus. Bioresour Bioprocess 2015;2:22.

42. Chand P, Aruna A, Maqsood AM, Rao LV. Novel mutation method for increased cellulase production. J Appl Microbiol 2005;98:318-23.

43. Fei R, Long C, Shuangli X, Qunyi T. Enhanced acarbose production by Streptomyces M37 using a two-stage fermentation strategy. Pub Lib Sci One 2017;12:1-11.

44. Zhuge X, Liu L, Shin HD, Li J, Du G. Improved propionic acid production from glycerol with metabolically engineered Propionibacterium jensenii by integrating fed-batch culture with a pH-shift control strategy. J Bioresour Technol 2014;152:519-25. 